\title{
Animal-based medicines used in ethnoveterinary practices in the semi-arid region of Northeastern Brazil
}

\author{
WEDSON M.S. SOUTO ${ }^{1}$, RAYNNER R.D. BARBOZA ${ }^{1}$, MICHELLE S.P. ROCHA ${ }^{2,3}$, \\ RÔMULO R.N. ALVES ${ }^{4}$ and JOSÉ S. MOURÃO ${ }^{4}$ \\ ${ }^{1}$ Programa de Pós-Graduação em Ciências Biológicas (Zoologia), Departamento de Sistemática e Ecologia, \\ Universidade Federal da Paraíba, Via Expressa Padre Zé, s/n, Cidade Universitária, 58059-970 João Pessoa, PB, Brasil \\ ${ }^{2}$ Pós-Graduação em Desenvolvimento e Meio Ambiente (PRODEMA), Universidade Estadual da Paraíba (UEPB), \\ Avenida das Baraúnas, s/n, 58109-753 Campina Grande, PB, Brasil \\ ${ }^{3}$ Universidade Federal da Paraíba (UFPB), Núcleo de Estudos e Pesquisas dos Recursos do Mar (NEPREMAR), \\ sala PRODEMA, via Expressa Padre Zé, s/n, Cidade Universitária, 58059-970 João Pessoa, PB, Brasil \\ ${ }^{4}$ Departamento de Biologia, Universidade Estadual da Paraíba, \\ Avenida das Baraúnas, s/n, Bodocongó, 58109-753 Campina Grande, PB, Brasil
}

Manuscript received on April 23, 2010; accepted for publication on June 14, 2010

\begin{abstract}
This work documents the zootherapeutic practices in Ethnoveterinary medicine (EVM) of Pedra Lavrada $\left(6^{\circ} 45^{\prime} \mathrm{S}, 36^{\circ} 28^{\prime} \mathrm{W}\right)$, Northeastern Brazil. We interviewed 23 people (22 men and 1 woman), who provided information on animal species used as remedies, body parts used to prepare the remedies, and illnesses for which the remedies were prescribed. We calculated the use-value to determine the most important species. Interviewees cited 11 animal taxa. The main species mentioned were ram - Ovis aries (UV=0.89), crab-eating fox - Cerdocyon thous (UV=0.79), common green iguana - Iguana iguana (UV=0.79), and South American rattlesnake - Caudisona durissa (Linnaeus, 1758) (UV=0.74). The most frequently cited treatments concerned to inflammatory and dermatological ailments or conditions, as well as to obstetric disorders. Similar to other studies, local ethnoveterinary establishes connections with human ethnomedicine. The results suggest that similarities in the repertoire of medicinal resources chosen by local residents reflect the local accessibility/ availability of the resources. Our results help to preserve ethnoveterinary knowledge, which is important in enhancing our understanding on the relationship among humans, society and nature, and also to elaborate more effective strategies for conserving natural resources. Other studies for scientific validation of the effects and side effects of these zootherapeutic products are needed before they can be recommended or not for use.
\end{abstract}

Key words: Ethnoveterinary, livestock, traditional knowledge, traditional remedies, zootherapy.

\section{INTRODUCTION}

Traditional veterinary medicine is very important in developing countries where conventional remedies for animal health care are inaccessible or unaffordable to poor rural farmers (McGaw et al.

Correspondence to: Wedson Medeiros Silva Souto

E-mail:wedson@1ive.com
2007). About $80 \%$ of people in the world today rely on folk (or traditional) medicine for treating both human and animal diseases (Iqbal et al. 2003). According to the United Nations Food and Agricultural Organization (FAO), the lack of drugs to treat diseases and infections results in losses of $30-35 \%$ in the breeding sector of many developing 
countries, where poor animal health remains the major constraint to increased production (FAO 2002). Problems of service delivery to such groups are often exacerbated by a multitude of other factors (Muhammad et al. 2005), and these factors have helped to maintain traditional treatment practices in these countries and fostered research on this subject (Muhammad et al. 2005). The extension of conventional medical/veterinary services is particularly difficult and costly in developing world nations where the necessary infrastructure (roads, clinics, labs, cold chains, etc.) is poorly developed and where much of the populace and its livestock reside in remote, rural areas or may be nomadic or transhumant (McCorkle and Green 1998).

Nonetheless, much effort is needed in research and integration of the ethnoveterinary practices activities in developing countries (Mathias and McCorkle 1997). In many native and local stock raising communities, if not all, a considerable proportion of useful ethno-knowledge and traditional animal health care practices remain unknown to date, albeit their increased demand to be integrated into primary animal health care delivery systems for a wider use by rural and periurban communities (Wanzala et al. 2005). Because traditional, native, medical practices have been in most cases either discontinued or greatly modified, there is much about them that will never be known (Lawrence 1998).

In Northeastern of Brazil, animal species have been medicinally used by indigenous society for millennia and by descendants of the European settlers for the last four centuries. In this region, especially in the semi-arid region (Caatinga biome), through the centuries, the local descendants of Amerindians, Africans, and Europeans learned to use the native natural resources, but also imported resources from the Old World to use in treating illnesses or infirmities in themselves and their livestock. Zootherapies form an integral part of the local culture, and information about animals and their uses are passed from generation to generation through oral folk lore (Alves and Alves 2011, Alves et al. 2009). The adaptation of the various human groups to the rich biological resources generated invaluable local knowledge systems that include extensive information on animal uses in general and medicinally useful species in particular (Alves and Rosa 2007).

The use of animals for medicinal purposes is part of a body of traditional knowledge that is increasingly becoming more relevant to discussions on conservation biology, public health policies, sustainable management of natural resources, biological prospection and patents (Alves and Rosa 2005, Alves et al. 2010a, b, c, Souto et al. 2009). However, little attention has been paid to the cultural, medical, economic, or ecological significance of zootherapeutic practices, even though the Brazilian federal government's National Policy of Pharmaceuticals (Politica Nacional de Medicamentos, Portaria $\mathrm{n}^{\circ}$ 3916/98) specifies that 'the support to research aiming to use the therapeutic potential of the national flora and fauna, with emphasis on certification of their medical properties, should be continued and expanded'.

Nonetheless, some issues become urgent to understand: (1) How many medicinal animals are used in the local EVM?, (2) Is this knowledge representative when compared to the use of animalbased medicines for humans?, (3) Does the local EVM have links with human ethnomedicine? (4) which are the possible impacts for the local fauna? In this context, the present study contributes to the documentation of the animals utilized as medicines in EVM among a group of inhabitants of the rural area in municipal district of Pedra Lavrada, inserted in the Caatinga Biome, Paraíba State.

\section{MATERIALS AND METHODS}

\section{THE STUdy Site}

The municipal district of Pedra Lavrada $\left(6^{\circ} 45^{\prime} \mathrm{S}\right.$, $\left.36^{\circ} 28^{\prime} \mathrm{W}\right)$ is situated in the state of Paraíba, Northeastern Brazil, in the microregion of Seridó. 
It occupies an area of approximately $352 \mathrm{~km}^{2}$ and is located $183 \mathrm{~km}$ from the state capital of João Pessoa. The municipal district was estimated to have a population of 6,810 inhabitants in 2007 , with 2,520 living in the urban zone, and 4,290 in the rural areas (IBGE 2008). The main economic activities of the municipality are subsistence agriculture (mainly sweet potato, beans and cassava) and livestock comprising cattle (3,426 head), goats (3,289 head), sheep (1,163 head) and fowl (more than 2,500 head) (IBGE 2008). In the studied area, livestock breeding is a predominantly male activity. With regard to monthly income, most interviewees (73.91\%) earned the minimum monthly wage $(\mathrm{R} \$ 415=\mathrm{US} \$ 176.89)$ or less.

\section{PROCEDURES}

Fieldwork was carried out during the period of November 2006 to March 2007. During the first contacts with the local population, an attempt was made to identify people with a specialized knowledge of medicinal animal use, following the procedures of Davis and Wagner (2003). A total of 23 inhabitants (22 men and 1 woman) were interviewed in both urban and rural areas, of which 19 were classified in the informers' category consisting of useful ' $n$ ' for data analysis. Interviewees ranged in age from 23 to 87 years (the average age being 55.8 years).

The data were collected through a combination of semi-structured and as open-ended interviews (Huntington 2000). Local residents were asked to provide the local name of the animal used as remedy; parts used as medicine; conditions treated with the remedy; preparation and usage; restrictions of use; adverse effects linked to the use; use of live or dead animals; how animals were obtained; storage conditions; collection sites; gear used to collect the animals; efficacy of the remedies; how knowledge was acquired by the interviewees; reliance on animal-based remedies; and why the interviewee used animal-based remedies in ethnoveterinary medicine. Prior informed consent was obtained for all interviews conducted. All of the interviewees raised (or had risen) livestock. Verification tests were performed to determine the consistency and validity of the responses (for analysis and data control) by repeating details of the interviews in synchronic situations. The ethical approval for the study was obtained from the Ethics committee of the Universidade Estadual da Paraíba.

Vernacular names of species were recorded as cited during interviews; zoological material was identified with the aid of specialists, through (a) the examination of specimens in the study area, (b) photographs of the animals or their parts, and (c) vernacular names, with the aid of taxonomists familiar with the fauna in the study area.

\section{DATA ANALYSIS}

The use-value was calculated for each species (adapted from the method proposed by Phillips and Gentry (1993), a quantitative method that demonstrates the relative importance of species known locally. This value was calculated using the following formula:

$\mathrm{UV}=\sum \mathrm{U} / \mathrm{n}$

where UV is the use-value of a species, $U$ the number of citations per species, and $n$ the number of informants. The use-value of each species is based solely on the importance attributed by the informants themselves and does not depend on any evaluation of the researcher (Albuquerque et al. 2005, Alves et al. 2009).

\section{RESULTS AND DISCUSSION}

The results in Table I summarize the names (vernacular and scientific) of medicinal animals, the parts used, ailments or conditions treated, and the mode of preparation and/or use. A total of 11 animals 
were used as medicines by inhabitants and livestock raisers in local EVM. Mammals and reptiles were the taxonomic groups most represented (4 species each), followed by birds (2) and fishes (1). The predominance of vertebrates reported in our study is in line with studies about the use of animal-based remedies in human ethnomedicine (see Alves et al. 2007, Negi and Palyal 2007, Van and Tap 2008).

The use-value (UV) of zootherapeutic resources was moderate. It ranged from 0.11 to 0.89 . The most important medicinal species were ram - Ovis aries Linnaeus, 1758 ( $\mathrm{n}=17, \mathrm{UV}=0.89)$, crab-eating fox - Cerdocyon thous (Linnaeus, 1766) $(\mathrm{n}=15, \mathrm{UV}=0.79)$, common green iguana - Iguana iguana (Linnaeus, 1758) $(\mathrm{n}=15, \mathrm{UV}=0.79)$ and South American rattlesnake - Caudisona durissa (Linnaeus, 1758) $(\mathrm{n}=14, \mathrm{UV}=0.74)$. Previous studies have identified these species as commonly used in Brazilian traditional medicine (see Alves 2009, Alves et al. 2007). In Pernambuco State, fat or suet of ram is used to treat pain, rheumatism, joint problems and lumps (Alves et al. 2008a). Barboza et al. (2007) reported that the ram is a major zootherapic animal used in traditional veterinary medicine in the municipality of Cubati, Brazil, where livestock raisers often utilize that animal's fat for treating rheumatism, injuries, "oca" (bovine gangrenous coryza) and other diseases. These findings are very similar to the results of this particular research. C. durissa uses in traditional medicine have been reported frequently in Brazil (Alves et al. 2008b), besides being utilized zootherapeutically for injuries in cattle (Barboza et al. 2007). The Rattlesnake and common green iguana are some of the oldest species of the Brazilian pharmacopoeia, and their medical uses date back to colonial times (Almeida 2005). The frequent use of a species for a society may be an indication that it constitutes a cultural keystone species. This term refers to those culturally important species that are associated with a group's cultural identity (Albuquerque and Oliveira 2007). Garibaldi and
Turner (2004) listed several criteria used to identify cultural keystone species, including the intensity, type and multiplicity of uses, as well as persistence and memory of use in spite of cultural change, and occupying a unique position in the culture.

All medicinal animals used by local residents were obtained within the limits of the studied site through capture and killing of specimens. The links between the communities and their surrounding landscape became apparent when relating the species used as remedies to the habitat types found in the study site. Most animals inventoried were from terrestrial habitats (7 species) - a reflection of main habitat types found in the surveyed area, located in the semi-arid region, and of the types of domestic animals used as medicines. Similarly, Adeola (1992) has shown that in Nigeria the utilization of animals was related to the ecological zone in which the people lived, and to the relative abundance of species in each zone. In this perspective, Phillips and Gentry (1993), investigating the useful plants of Tambopata, Peru, reported that plants easily found would offer more possibilities for local populations to experiment with their uses, thus having a greater probability of being introduced into the local culture. As remarked by Alves and Rosa (2006), the use of local, more easily accessible resources is possibly related to historic aspects (i.e., medicinal knowledge focusing on species familiar to the locals, reflecting transmission of knowledge through generations) and to financial constraints that limit access to alloctonous resources.

In no case was the whole animal employed, but rather body parts or by-products such as bones, fat, feathers, leather, milk and suets that were used for 14 different veterinary purposes, mainly related to inflammatory, and dermatological ailments or conditions (e.g., furunculosis, dermal nodules, wounds, and swellings) and obstetric disorders (uterus prolapse). Coincidentally, these categories of ailments are the ones on which traditional veterinary medicine has mostly focused (see Cox and Balick 1994). 
TABLE I

Zootherapeutics resources used in Ethnoveterinary medicine of Pedra Lavrada, NE Brazil.

\begin{tabular}{|c|c|c|c|c|c|}
\hline Family/Species/Local name & $\begin{array}{l}\text { Number of } \\
\text { mentions }\end{array}$ & $\begin{array}{c}\text { Use-value } \\
\text { (UV) }\end{array}$ & $\begin{array}{l}\text { Part used and way } \\
\text { of administration }\end{array}$ & Disease (or illness) & Animal(s) treated \\
\hline \multicolumn{6}{|l|}{ FISHES } \\
\hline \multicolumn{6}{|l|}{ Curimatidae } \\
\hline $\begin{array}{l}\text { Prochilodus sp.* } \\
\text {-"Curimatã" }\end{array}$ & 2 & 0.11 & Fat (1) & $\begin{array}{l}\text { "Estrepes" (Suck a } \\
\text { splinter out of skin) }\end{array}$ & $\begin{array}{l}\text { ct, da, go, } \\
\text { ho, pi, sh }\end{array}$ \\
\hline \multicolumn{6}{|l|}{ REPTILES } \\
\hline \multicolumn{6}{|l|}{ Chelidae } \\
\hline $\begin{array}{l}\text { Phrynops geoffroanus } \\
\text { (Schweigger, 1812)* - } \\
\text { Geoffroy’s side-necked turtle, } \\
\text { "cágado d'água" }\end{array}$ & 5 & 0.26 & Fat (1) & $\begin{array}{l}\text { Wounds, "Estrepes" } \\
\text { (suck a splinter out of } \\
\text { skin), dermal nodules }\end{array}$ & $\begin{array}{l}\text { ct, da, go, } \\
\text { ho, pi, sh }\end{array}$ \\
\hline \multicolumn{6}{|l|}{ Iguanidae } \\
\hline $\begin{array}{l}\text { Iguana iguana } \\
\text { (Linnaeus, 1758)* } \\
\text { - Common Green, "Camaleão" }\end{array}$ & 15 & 0.79 & $\begin{array}{c}\text { Bones }(2), \\
\text { fat }(1), \\
\text { leather }(1,2,3)\end{array}$ & $\begin{array}{l}\text { "Estrepes" (Suck a } \\
\text { splinter out of skin), } \\
\text { Arthritis in cattle } \\
\text { and horses }\end{array}$ & $\begin{array}{l}\text { ct, da, go, } \\
\text { ho, pi, sh }\end{array}$ \\
\hline \multicolumn{6}{|l|}{ Teiidae } \\
\hline \multirow[t]{2}{*}{$\begin{array}{l}\text { Tupinambis merianae } \\
\text { (Duméril \& Bibron, 1839)* } \\
\text { - Lizard teju, "tegu”, "tejuaçúu" }\end{array}$} & 13 & 0.68 & Fat $(1,4)$ & $\begin{array}{l}\text { Wounds, "Estrepes" } \\
\text { (suck a splinter out of } \\
\text { skin), Inflammations } \\
\text { in general }\end{array}$ & $\begin{array}{l}\text { ct, da, go, } \\
\text { ho, pi, sh }\end{array}$ \\
\hline & & & & Uterus prolapse & co, go, ma, sh \\
\hline \multicolumn{6}{|l|}{ Viperidae } \\
\hline \multirow[t]{2}{*}{$\begin{array}{l}\text { Caudisona durissa (Linnaeus, } \\
\text { 1758)* - South American } \\
\text { rattlesnake, "Cascavel" }\end{array}$} & 12 & 0.63 & Fat $(1,4,5)$ & Uterus prolapse (4), & $\begin{array}{l}\mathrm{co}, \mathrm{go} \\
\mathrm{ma}, \mathrm{sh}\end{array}$ \\
\hline & & & & $\begin{array}{c}\text { Inflammations } \\
\text { and swellings (1), } \\
\text { Rheumatism in cattle } \\
\text { and horses (5) }\end{array}$ & $\begin{array}{l}\text { ct, da, go, } \\
\text { ho, pi, sh }\end{array}$ \\
\hline \multicolumn{6}{|l|}{ MAMMALS } \\
\hline \multicolumn{6}{|l|}{ Bovidae } \\
\hline \multirow[t]{3}{*}{$\begin{array}{l}\text { Bos taurus Linnaeus, } 1758 \text { - } \\
\text { domestic cattle, "Boi", "vaca" }\end{array}$} & 7 & 0.37 & $\begin{array}{c}\text { Homemade } \\
\text { butter, milk (5) }\end{array}$ & Mastitis & ct, go, sh \\
\hline & & & Homemade butter (1) & Swellings & ct, da, go, ho, pi, sh \\
\hline & & & Suet (6) & $\begin{array}{l}\text { Bovine gangrenous } \\
\text { coryza }\end{array}$ & ct \\
\hline \multirow[t]{4}{*}{$\begin{array}{l}\text { Ovis aries Linnaeus, } 1758 \\
\text { - ram, "Carneiro" }\end{array}$} & 17 & 0.89 & Castrated ram suet (1) & $\begin{array}{l}\text { Fracture, wounds, } \\
\text { "Estrepes" (suck a } \\
\text { splinter out of skin) }\end{array}$ & $\begin{array}{l}\text { ct, da, go, } \\
\text { ho, pi, sh }\end{array}$ \\
\hline & & & Castrated ram suet (5) & $\begin{array}{l}\text { Inflammations or } \\
\text { swellings }\end{array}$ & $\begin{array}{l}\text { ct, da, go, } \\
\text { ho, pi, sh }\end{array}$ \\
\hline & & & Castrated ram suet (5) & Arthritis & ct, go, ho, pi, sh \\
\hline & & & Castrated ram suet (5) & Rheumatism & ct, ho \\
\hline
\end{tabular}


TABLE I (continuation)

\begin{tabular}{|c|c|c|c|c|c|}
\hline Family/Species/Local name & $\begin{array}{c}\text { Number of } \\
\text { mentions }\end{array}$ & $\begin{array}{c}\text { Use-value } \\
\text { (UV) }\end{array}$ & $\begin{array}{c}\text { Part used and way of } \\
\text { administration }\end{array}$ & Disease (or illness) & $\begin{array}{c}\text { Animal(s) } \\
\text { treated }\end{array}$ \\
\hline & & & Castrated ram suet (6) & Bovine gangrenous coryza & $\mathrm{ct}$ \\
\hline \multicolumn{6}{|l|}{ Canidae } \\
\hline \multirow[t]{3}{*}{$\begin{array}{l}\text { Cerdocyon thous } \\
\text { (Linnaeus, 1766)* } \\
\text { - Crab-eating Fox, "Raposa" }\end{array}$} & 15 & 0.79 & Fat (1) & $\begin{array}{l}\text { Furunculosis, inflammations } \\
\text { in general, Wounds, } \\
\text { "Estrepes" (suck a splinter } \\
\text { out of skin), dermal nodules }\end{array}$ & $\begin{array}{l}\text { ct, da, go, } \\
\text { ho, pi, sh }\end{array}$ \\
\hline & & & Fat (4) & Uterus prolapse & co, go, ma, sh \\
\hline & & & Fat (5) & Rheumatism & ct, ho \\
\hline \multicolumn{6}{|l|}{ Suidae } \\
\hline \multirow[t]{4}{*}{$\begin{array}{l}\text { Sus scrofa domesticus Linnaeus, } \\
1758 \text { - domestic pig, "porco" }\end{array}$} & 12 & 0.63 & $\begin{array}{l}\text { Fat, fat of the } \\
\text { pig scrotum (1) }\end{array}$ & $\begin{array}{c}\text { Inflammations in general, } \\
\text { wounds, "Estrepes" } \\
\text { (suck a splinter out of skin), } \\
\text { dermal nodules }\end{array}$ & $\begin{array}{l}\text { ct, da, go, } \\
\text { ho, pi, sh }\end{array}$ \\
\hline & & & $\begin{array}{l}\text { Fat, fat of the } \\
\text { pig scrotum (1) }\end{array}$ & Mastitis & ct, go, sh \\
\hline & & & Fat (1) & Rheumatism & ct, ho \\
\hline & & & Fat (1) & Scabies & ct, go, sh \\
\hline \multicolumn{6}{|l|}{ BIRDS } \\
\hline \multicolumn{6}{|l|}{ Phasianidae } \\
\hline $\begin{array}{l}\text { Gallus gallus domesticus } \\
\text { (Linnaeus, 1758) } \\
\text { - domestic chicken, "Galinha" }\end{array}$ & 11 & 0.58 & Fat (1) & $\begin{array}{c}\text { Inflammations in general, } \\
\text { wounds, "Estrepes" } \\
\text { (suck a splinter out of skin) }\end{array}$ & $\begin{array}{l}\text { ct, da, go, } \\
\text { ho, pi, sh }\end{array}$ \\
\hline \multicolumn{6}{|l|}{ Tinamidae } \\
\hline \multirow[t]{2}{*}{$\begin{array}{l}\text { Nothura maculosa cearensis } \\
\text { Naumburg, 1932* } \\
\text { - spotted Nothura - "Codorniz" }\end{array}$} & 11 & 0.58 & Feathers (2) & Snake bites & $\begin{array}{l}\text { ct, da, go, } \\
\text { ho, pi, sh }\end{array}$ \\
\hline & & & Feathers (2) & Wounds & $\begin{array}{l}\text { ct, da, go, } \\
\text { ho, pi, sh }\end{array}$ \\
\hline
\end{tabular}

Legend: (1) Topical use; (2) the action of toast and triturate results in a powder that is applied on the affected area; (3) use as poultice; (4) specialized technique in which the uterus, after the externalization, is moistened and 'washed' with fat or other substance considered locally as healing and then carefully set back into the animal; (5) topical use associated with massage on the affected area; (6) for treating 'oca' (Bovine gangrenous coryza). The horn of cattle is usually sawed and filled in with fats/suet or other substances considered therapeutic; da - domestic animals in general, co - cow, ct - cattle, go - goats, ho - horses, ma - mare, pi - pigs, sh - sheeps. * - wild species

The main parts used for therapeutic purposes are fats and suets. These resources are obtained from 10 species. Other studies also highlight fat as one of the main forms of zootherapy in several parts of the world (Alves et al. 2007, El-Kamali 2000), suggesting that the intensive use of fats and suet as zootherapeutic medicines may be due to the fact that the animals used for medicinal purpose are generally vertebrates with significant amounts of fatty tissue that is easy to obtain, store, and transport. Indeed, as Begossi and Braga (1992) state, fat is widely used in Brazilian folk medicines. Despite that the validity of these medicines is still to be determined, it is possible that there is a relationship between local zootherapeutic products and the regional flora. According to Rastogi and Kaphle (2008), if animals 
eat plants with certain pharmacological properties, these properties will be reflected in their secretions and tissues. This characteristic is particularly important if we consider that in Northeastern Brazil there are at least 389 medicinal plants in the local inhabitants' pharmacopoeia, and 275 are considered spontaneous (Albuquerque et al. 2007).

Different ways of preparing and administering animal remedies were reported by the interviewees. Hard parts, in this case bones and feathers, were generally sun-dried, grated and crushed to powder to be then applied topically. Seixas and Begossi (2001) state that the parts are burned as a form of sterilization to eliminate the possibility of decomposition of organic materials. Fats were only administered topically, similar to the findings of Alves and Rosa (2006), Alves et al. (2009) and Silva (2008).

Local EVM establishes connections with human ethnomedicine. According to interviewees, all treatments were based on a treatment of identical or similar conditions in humans, except those administered for uterus prolapse and bovine gangrenous coryza. Worldwide, parallels between human and animal ethnomedicine are myriad, spanning not only health care concepts, beliefs, and practitioners, but also nearly all known modes of administration of remedies (McCorkle and Martin 1998, Souto et al. 2011a, b). These results support previous studies (e.g., Mathias-Mundy (1989), Pieroni et al. (2006), Scarpa (2000)) that have revealed that, in most traditional societies, there is no clear division between EVM and human ethnomedicine. In Mediterranean, for instance, nearly half of the recorded veterinary plant uses for mammals uncovered in this survey have also been recorded in the same areas in human folk medicine, suggesting a strong link between human and veterinary medical practices, and perhaps also suggesting the adaptive origins of a few medical practices (Pieroni et al. 2006). The use of folk remedies to treat diseases or ailments in animals based on similar or identical illnesses that attack humans was denominated 'human models for animal diseases' by Barboza et al. (2007). The relationships between ethnoveterinary and human ethnomedicine can be easily explained in this perspective, as the main stock animals (e.g. cattle, sheep, goats, pigs, among others) are mammals (Confessor et al. 2009), which often have health problems that are similar to humans with identical symptoms; these similarities have been noted by many different communities (Alves et al. 2010d). Our data demonstrate that a significant part of traditional knowledge about the use of medicinal animals in local EVM is linked to traditional human medicines and contributes to considering these practices as 'one ethnomedicine'.

Not all ethnoveterinary practices provide more effective or ideal solutions to all animal health problems when compared to the Western veterinary science (McCorkle and Mathias-Mundy 1992). Nevertheless, the chemical constituents and pharmacological actions of certain animal products are known to some extent, but more ethnopharmacological studies focusing on animal remedies are needed in order to better define the eventual therapeutic usefulness of this class of biological remedies (Pieroni et al. 2002). Research is also needed to establish whether medicinal animals have fewer long term adverse complications, such as antibiotic resistance, than commercial drugs (Souto et al. 2009).

Moreover, the utilization of wild species from the local fauna must be taken into account when in planning for the management and sustainable use of wild animals. It is necessary to preserve ethnoveterinary knowledge, which is important for enhancing our understanding on the relationship among human, society and nature, and also for devising more effective strategies for conserving natural resources. As pointed out by Mathias and Perezygrovas (1997), promoting ethnoveterinary medicine means helping local people to use their experience and knowledge to build on their own strategies and resources. 
Given the increased use of animals in traditional medicines, the scholar investigation of studies on medicinal uses of animals and their products should not be neglected and should be considered as an important complementary body of knowledge (Alves 2008). Traditional knowledge on the use of animals in tradicional medicine (ethnomedicine or folk veterinary medicine) needs to be approached as an integrated and holistic structure by various branches of science in order to achieve a truly interdisciplinary understanding of the phenomenon of traditional medicine.

\section{CONCLUSIONS}

Our studies indicated that 11 medicinal animals were being used in the ethnoveterinary medicine of Pedra Lavrada (Northeastern Brazil) to treat 14 ailments - thus indicating the rich ethnomedical knowledge of the local population in relation to zootherapy. Although the repertory of animal-based remedies is less than the use of zootherapeutics for humans, this study contributes to that future studies consider the zootherapeutic practices in EVM as an important part of the Brazilian pharmacopoeia, which has been neglected in comparison to human ethnomedicine. Our results also demonstrated that the traditional knowledge on the use of animal-based medicines in ethnoveterinary practices of the semi-arid region of Paraíba State probably co-evolved along with traditional knowledge in human ethnomedicine, since practically all the methods of treatment by using zootherapeutics were based on the same treatment of similar or identical problems that affect humans.

Zootherapy represents an alternative to official veterinary practices in the semi-arid region of Northeastern Brazil, and has also become part of local popular medicine. There is a growing recognition that knowledge of traditional medicine (human or veterinary) is important not only because of its potential to discover new treatments, but also because of its socioeconomic, conservationist and cultural components. As pointed out by Bodeker and Kronenberg (2002), public health researchers must lead the development of a research agenda that considers social, cultural, political and economic contexts, to maximize the potential contribution of TM to healthcare systems globally.

We suggest that besides the validation of these traditional remedies, there is a great necessity to educate the local population and healers to adopt conservation measures as necessary, since uncontrolled use of medicines derived from wild animals can lead to the loss of their source medicinal material.

\section{ACKNOWLEDGMENTS}

The authors are grateful to all the interviewees who contributed information to this research. We also thank the researchers of the Departamento de Sistemática e Ecologia, Universidade Federal da Paraíba, for the identification of some species.

\section{RESUMO}

Este trabalho registra as práticas zooterapêuticas na medicina etnoveterinária no município de Pedra Lavrada, Nordeste do Brasil. Entrevistaram-se 23 pessoas (22 homens e uma mulher) os quais forneceram informações sobre as espécies usadas como remédios, as partes do corpo usadas para preparar os remédios e as doenças tratadas. Calculou-se o Valor de Uso a fim de determinar quais espécies eram mais importantes. Os entrevistados reportaram 11 animais usados medicinalmente. As principais espécies citadas foram: o carneiro - Ovis aries (UV=0,89), a raposa - Cerdocyon thous (UV=0,79), o camaleão - Iguana iguana $(\mathrm{UV}=0,79)$ e a cascavel - Caudisona durissa (Linnaeus, 1758) (UV=0,74). Os tratamentos mais freqüentemente citados relacionaramse a doenças inflamatórias, dermatológicas e desordens obstetrícias. Semelhante a outros estudos, a etnoveterinária local estabelece conexões com a etnomedicina para humanos. Os resultados sugerem que similaridades no repertório de recursos medicinais escolhidos pelos moradores locais refletem a acessibilidade/disponbilidade dos recursos. Nosso resultados ajudam a preservar o 
conhecimento etnoveterinário, o qual é importante para aumentar nossa compreensão das relações entre seres humanos, a sociedades e a natureza, e também elaborar estratégias mais efetivas para conservar os recursos naturais. Outros estudos para validação científica da eficácia e efeitos colaterais destes produtos zooterapêuticos são necessários antes que possam ser recomendados ou não para o uso.

Palavras-chave: Etnoveterinária, animais de rebanho, conhecimento tradicional, remédios tradicionais, zooterapia.

\section{REFERENCES}

ADEOLA MO. 1992. Importance of wild Animals and their parts in the culture, religious festivals, and traditional medicine, of Nigeria. Environ Conserv 19: 125-134.

AlbuQUERQUE UP, ANDRADE LHC AND SILVA ACO. 2005. Use of plant resources in a seasonal dry forest (Northeastern Brazil). Acta bot bras 19: 27-38.

Albuquerque UP, MedeIros PM, Almeida ALS, Monteiro JM, Neto EMFL, Melo JG AND Santos JP. 2007. Medicinal plants of the caatinga (semi-arid) vegetation of NE Brazil: A quantitative approach. J Ethnopharmacol 114: 325-354.

ALBUQUERQUE UP AND OLIVEIRA RF. 2007. Is the use-impact on native caatinga species in Brazil reduced by the high species richness of medicinal plants? J Ethnopharmacol 113: $156-170$.

AlmeIDA AV. 2005. Prescrições zooterápicas indígenas brasileiras nas obras de Guilherme Piso (1611-1679). In: ALVES AGC ET AL. (Eds), Atualidades em Etnobiologia e Etnoecologia, Recife, Brasil.

Alves RRN. 2008. Animal-Based Remedies as Complementary Medicine in Brazil. Forsch Komplement/ Res Complement Med 15: 226-227.

ALVES RRN. 2009. Fauna used in popular medicine in Northeast Brazil. J Ethnobiol Ethnomed 5: 1-30.

Alves RRN AND ALVES HN. 2011. The faunal drugstore: Animal-based remedies used in traditional medicines in Latin America. J Ethnobiol Ethnomed 7: 1-43.

Alves RRN, BARBosa JAA, SANTOS SLDX, SOUTO WMS AND BARBOZA RRD. 2009. Animal-based Remedies as Complementary Medicines in the Semi-arid Region of Northeastern Brazil. Evid Based Complement Alternat Med. doi:10.1093/ecam/nep 134: 1-15.

Alves RRN, BARBOZA RRD AND SOUTO WMS. 2010b. A Global overview of canids used in traditional medicines. Biodivers Conserv 19: 1513-1522.

ALVES RRN, BARBOZA RRD AND SOUTO WMS. 2010d. Plants Used in Animal Health Care in South and Latin America: An Overview. In: KATERERE RD AND LUSEBA D (Eds), Ethnoveterinary Botanical Medicine: Herbal Medicines for Animal Health, New York, USA.
ALVES RRN, Lima HN, TAVARES MC, SOUtO WMS, BARBOZA RRD AND VASCONCELlOS A. 2008a. Animal-based remedies as complementary medicines in Santa Cruz do Capibaribe, Brazil. BMC Complement Altern Med 8: 1-44.

ALVES RRN, OLIVEIRA MDGG, BARBOZA RRD AND LOPEZ LCS. 2010c. An ethnozoological survey of medicinal animals commercialized in the markets of Campina Grande, NE Brazil. Hum Ecol Rev 17: 11-17.

ALVES RRN AND ROSA IL. 2005. Why study the use of animal products in traditional medicines? J Ethnobiol Ethnomed 1: $1-5$.

ALVES RRN AND RosA IL. 2006. From cnidarians to mammals: The use of animals as remedies in fishing communities in NE Brazil. J Ethnopharmacol 107: 259-276.

ALVES RRN AND RoSA IL. 2007. Zootherapeutic practices among fishing communities in North and Northeast Brazil: A comparison. J Ethnopharmacol 111: 82-103.

ALVES RRN, Rosa IL AND SANTANA GG. 2007. The Role of Animal-derived Remedies as Complementary Medicine in Brazil. BioScience 57: 949-955.

ALVES RRN, SOUTO WMS AND BARBOZA RRD. 2010a. Primates in traditional folk medicine: a world overview. Mammal Rev 40: 155-180.

ALVES RRN, VIEIRA WLS AND SANTANA GG. 2008b. Reptiles used in traditional folk medicine: conservation implications. Biodivers Conserv 17: 2037-2049.

BARBOZA RRD, SOUTO WMS AND MOURÃo JS. 2007. The use of zootherapeutics in folk veterinary medicine in the district of Cubati, Paraíba State, Brazil. J Ethnobiol Ethnomed 3: 14.

Begossi A AND Braga FMS. 1992. Food taboos and folk medicine among fishermen from the Tocantins River. Amazoniana 12: 101-118.

Bodeker G And Kronenberg F. 2002. A Public Health Agenda for Traditional, Complementary, and Alternative Medicine. Am J Public Health 92: 1582-1591.

Confessor M, Mendonca L, Mourao J And Alves R. 2009. Animals to heal animals: ethnoveterinary practices in semi-arid region, Northeastern Brazil. J Ethnobiol Ethnomed 5: 1-37.

COX PA AND BALICK MJ. 1994. The ethnobotanical approach to drug discovery. Scien Am June 1994, p. 60-65.

DAVIS A AND WAGNER J. 2003. Who Knows? On the Importance of Identifying "Experts" When Researching Local Ecological Knowledge. Hum Ecol 31: 463-489.

EL-KAMALi HH. 2000. Folk medicinal use of some animal products in Central Sudan. J Ethnopharmacol 72: 279-282.

FAO. 2002. Genetics and animal health-Splotlight, $1^{\text {st }}$ ed., Rome: FAO, 32 p.

GARIBALDI A AND TURNER N. 2004. Cultural Keystone Species: Implications for Ecological Conservation and Restoration. Ecol Soc 9: 1-18.

Huntington HP. 2000. Using Traditional Ecological Knowledge in Science: Methods and Applications. Ecol Appl 10: 1270-1274.

IBGE.2008. IBGE-CanalCidades@. [http://www.ibge.gov.br/ cidadesat/default.php]. [13 jun. 2009]. 
IQBAL Z, AKHTAR MS, SINDHU Z-U-D, KHAN MN AND JABBAR A. 2003. Herbal Dewormers in Livestock - A Traditional Therapy. Intern J Agri Biol 5: 199-206.

LAWRENCE EA. 1998. Human and horse medicine among some Native American groups. Agri Hum Val 15: 133-138.

Mathias E AND MCCORKLE CM. 1997. Animal health. In: BUNDERS J ET AL. (Eds), Biotechnology: Building on Farmers' Knowledge, Basingstoke, UK

Mathias E AND Perezygrovas R. 1997. Application of ethnoveterinary medicine-where do we stand? In: International Conference on 'Ethnoveterinary Medicine Alternatives for Livestock Development', Pune, India: BAIF Development Research Foundation.

MATHIAS-MUNDY E. 1989. Of herbs and healers. LEISA M 5: $20-22$.

MCCORKLE CM AND GREEN EC. 1998. Intersectoral healthcare delivery. Agri Hum Val 15: 105-114.

MCCORKLE CM AND MARTIN M. 1998. Parallels and potentials in animal and human ethnomedical technique. Agri Hum Val 15: 139-144.

MCCORKLE CM AND MATHIAS-Mundy E. 1992. Ethnoveterinary Medicine in Africa. J Inter Afr Inst 62: 59-93.

MCGAW LJ, VAN DER MERWE D AND ElofF JN. 2007. In vitro anthelmintic, antibacterial and cytotoxic effects of extracts from plants used in South African ethnoveterinary medicine. The Vet J 173: 366-372.

Muhammad G, Khan MZ, HuSSAIN MH, IQBal Z, IQBal M AND ATHAR M. 2005. Ethnoveterinary practices of owners of pneumatic-cart pulling camels in Faisalabad City (Pakistan). J Ethnopharmacol 97: 241-246.

Negi CS AND PALYAL V. 2007. Traditional Uses of Animal and Animal Products in Medicine and Rituals by the Shoka Tribes of District Pithoragarh, Uttaranchal, India. EthnoMed 1: 47-54.

Phillips O AND GENTRY AH. 1993. The Useful Plants of Tambopata, Peru: I. Statistical Hypotheses Tests with a New Quantitative Technique. Econ Bot 47: 15-32.

Pieroni A, GiUsti ME AND Grazzini A. 2002. Animal remedies in the folk medicinal practices of the Lucca and Pistoia Provinces, Central Italy. In: FLEURENTIN J ET AL. (Eds), Des sources du savoir aux médicaments du futur/from the sources of knowledge to the medicines of the future, Paris
PIERONI A ET AL. 2006. Circum-Mediterranean cultural heritage and medicinal plant uses in traditional animal healthcare: a field survey in eight selected areas within the RUBIA project. J Ethnobiol Ethnomed 2: 1-12.

RASTOGI S AND KAPHLE K. 2008. Sustainable Traditional Medicine: Taking the Inspirations from Ancient Veterinary Science. Evid Based Complement Alternat Med 5: 1-6.

SCARPA GF. 2000. Plants employed in traditional veterinary medicine by the criollos of the Northwestern Argentine Chaco. Darwiniana 38: 253-265.

SEIXAS CS AND BEGOSSI A. 2001. Ethnozoology of fishing communities from Ilha Grande (Atlantic forest coast, Brazil). J Ethnobiol 21: 107-135.

SILVAAL. 2008. Animais medicinais: conhecimento e uso entre as populações ribeirinhas do rio Negro, Amazonas, Brasil. Bol Mus Para Emílio Göeldi 3: 343-357.

SOUTO WMS, BARBOZA RRD, MOURÃo JS AND ALVES RRN. 2009. Zootherapy in Brazil: An Urgent Necessity of Interdisciplinary Studies. West Indian Med J 58: 494-495.

SOUTO WMS, MOURÃo JS, BARBOZA RRD AND ALVES RRN. 2011a. Parallels between zootherapeutic practices in ethnoveterinary and human complementary medicine in northeastern Brazil. J Ethnopharmacol 134: 753-767.

Souto WMS, Mourão JS, BARBoza RRD, MENDONÇA LET, LUCENA RFP, CONFESSOR MVA, VIEIRA WLS, MONTENEGRO PFGP, LOPEZ LCS AND ALVES RRN. 2011b Medicinal animals used in ethnoveterinary practices of the 'Cariri Paraibano', NE Brazil. J Ethnobiol Ethnomed 7: 1-20.

VAN NDN AND TAP N. 2008. An overview of the use of plants and animals in traditional medicine systems in Viet Nam, $1^{\text {st }}$ ed., Ha Noi, Viet Nam: TRAFFIC Southeast Asia, Greater Mekong Programme, $96 \mathrm{p}$.

WanZala W, Zessin KH, KyUle NM, BaUmanN MPO, MATHIAS E AND HASSANALi A. 2005. Ethnoveterinary medicine: a critical review of its evolution, perception, understanding and the way forward. Livestock Res Rur Devel 17: 1-29. 